\title{
The Effect of Inquiry Model on Students Higher Order Thinking Skills in Ecosystem
}

\author{
Zuriati Siska Saputri \\ Postgraduate Student, Department of Science Education \\ Universitas Negeri Medan \\ Medan, Indonesia \\ Zuriatisiska45@gmail.com
}

\author{
Hasruddin \\ Department of Science Education \\ Universitas Negeri Medan \\ Medan, Indonesia
}

\author{
R. Mursid \\ Department of Science Education \\ Universitas Negeri Medan \\ Medan, Indonesia
}

\begin{abstract}
This study aimed to find out the effect of Inquiry learning model on higher order thinking skills of students at ecosystem topic in grade 5 Elementary School (SD) Medan. The research applies experimental method with 2 classes are chosen by using random sampling technique. The class $5 \mathrm{~A}$ is taught by using Guided Inquiry model and the class 5B is taught by using Free Inquiry model. The research instruments are learning outcome tests whose validity, reliability, level of difficulty, and the discrimination index have been tested. The data are analyzed by using Covariate Analysis (Anacova). The results show that higher order thinking skills of experimental class students learning using guided inquiry model are higher than the control class students who are learning using free inquiry model.
\end{abstract}

Keywords—Inquiry; Higher Order Thinking Skills)

\section{INTRODUCTION}

Higher order thinking skills arise when someone receives new information and the information is entered into memory and the information is linked to each other to achieve a goal or find possible answers in answering a confusing situation [1]. Learning to find is a way of learning that will provide the best results. In addition, seen in terms of emotional satisfaction, finding the results give a higher satisfaction value compared to the results of giving. Through discovery activities, the learning process will involve more students because students can raise problems, identify problems, formulate hypotheses, test hypotheses based on data collection, create and compile tables or charts, interpret data, and finally draw conclusions [2].

The results of research conducted by Yennita (2010) shows that often learning that occurs in class is that the teacher only provides students with a number of mere memorized concepts, many teachers tend to use conventional methods. Teachers are less capable and less creative in choosing the right learning model [3]. The teacher tries so that students are able to memorize the material as much as possible in accordance with what is explained by the teacher. That learning is teacher-centered learning (one-way learning). In fact, the applicable curriculum directs learning that occurs in class is two way learning.

The application of teacher-centered learning methods results in low levels of student thinking, lack of mastery of concepts and students tend to be passive, reluctant, afraid or ashamed to express their opinions, circumstances like this will certainly disrupt the learning and creativity of students in learning activities [4]. If this is not followed up it will cause students to experience more difficulties in learning so students tend to have a lack of high-level thinking skills.

The problems described above occur because the learning model or method applied by the teacher is a conventional learning model in the form of lectures. The learning model is not suitable to be applied, as explained in the description above. To overcome these problems, it is necessary to apply the right learning model to improve the students learning outcomes. One learning model that can be used as a solution for this is the inquiry learning model.

Inquiry models allow students to use all mental process to find scientific concepts or principles and provide many advantages including increasing intelligence, helping students learn to do research, improve memory, avoid teaching and learning by memorizing, developing creativity, increasing aspirations, making teaching processes become student centered so that it can help better towards the formation of self-concept, giving more opportunities for students to accommodate and understand information [5].

Inquiry is the process of investigating a problem [6]. This means that inquiry is the process of finding out, researching, observing or investigating a problem. The inquiry model is a method that prepares students in a situation to conduct their own experiments widely in order to see what is happening, want to do something, ask questions, and find their own answer, and relate other findings, comparing what they find with those found by other students [7]. 
Inquiry model is divided into three, such as: (1) guided inquiry, the teacher guiding students to do activities by giving initial questions and directing a discussion; (2) free inquiry, in this inquiry students are facilitated to be able to identify problems and design the investigation process, and (3) modified free inquiry, this model of inquiry is a collaboration or modification of the two previous inquiry approaches. In this study, researchers will focus on two models of inquiry namely guided inquiry and free inquiry [8].

Higher order thinking skills include critical, logical, reflective and creative thinking [9]. High level thinking skills are activated when individuals get problems. Very complex problems often require complex solutions where the solution is obtained from a high level thinking process.

In the revised Bloom Taxonomy, high level abilities involves analysis (C4), evaluating (C5), and creating or creativity (C6) are considered high level thinking [10]. Anderson has conducted research and research has been included in the improvement of the existing Bloom Taxonomy. These changes are changing Bloom's Taxonomy from nouns to verbs. The difference between Bloom and Anderson Taxonomy can be seen in Table 1 as follows. The description and the key word of each category can be seen in Table 2.

TABLE 1. THE DIFFERENCE BETWEEN BLOOM AND ANDERSON TAXONOMY

\begin{tabular}{ll}
\hline \multicolumn{1}{c}{ Bloom Taxonomy } & Revised Bloom Taxonomy \\
\hline Knowledge & Remembering \\
Comprehension & Understanding \\
Application & Applying \\
Analysis & Analyzing \\
Synthesis & Evaluating \\
Evaluating & Creating \\
\hline
\end{tabular}

TABLE 2. THE DESCRIPTION AND THE KEY WORD OF REVISED BLOOM TAXONOMY

\begin{tabular}{cll}
\hline Category & \multicolumn{1}{c}{ Key word } & Level of thinking \\
\hline Remembering & $\begin{array}{l}\text { Mentioning } \\
\text { definitions, } \\
\text { imitating speech, }\end{array}$ & \\
stating structure, & \\
saying, repeating, & \\
stating & LOTS - Lower \\
Understanding & $\begin{array}{l}\text { Grouping, } \\
\text { describing, }\end{array}$ & Order Thinking \\
& explaining & \\
identification, \\
placing, reporting, \\
explaining, \\
translating, \\
paraphrasing
\end{tabular}
Applying
Choosing, demonstrating, portraying, using, illustrating, interpreting, scheduling, sketching, solving problems, writing

$\begin{array}{ll}\text { Analyzing } & \text { Reviewing, } \\ & \text { comparing, } \\ & \text { contrasting, } \\ & \text { differentiating, } \\ \text { discriminating, } & \text { separating, testing, } \\ & \text { experimenting, } \\ & \text { questioning. }\end{array}$

Evaluating

Giving argumentation, defending, stating, choosing, giving support, giving HOTS - High Order Thinking judgment, evaluating

$\begin{array}{ll}\text { Creating } & \text { Assembling, } \\ \text { changing, building, } \\ \text { creating, } \\ \text { designing, } \\ \text { establishing, } \\ \text { formulating, } \\ \text { writing }\end{array}$

From table 2 above, it can be seen that the ability to remember, understand and apply belongs to the Lower Order Thinking Skill (LOTS). This study will examine the ability of higher order thinking skills (HOTS) of elementary school fifth grade students which consists of the ability to analyze, evaluate, and create. To measure the higher order thinking skills of students, it is necessary to determine the indicators such as: (1) analyzing, involves the process of dividing matter into small parts and determining how the relationships between parts, each part and the overall structure. The key to analyzing is to study, compare, contrast, differentiate, discriminate, separate, test, conduct experiments, question; (2) evaluating, is defined as making decisions based on criteria and standards. The criteria most often used are quality, effectiveness, efficiency and consistency. The key words for evaluating are giving arguments, maintaining, stating, choosing, giving support, giving an assessment, evaluating; (3) creating, involves the process of arranging elements into a coherent or functional whole. The keywords for creating are assembling, changing, building, creating, designing, establishing, formulating and writing.

Inquiry-based learning is student-centered learning that aims to encourage students to develop intellectual discipline and thinking skills by giving questions. The questions are 
scientific questions that can lead to the investigation of the object of question.

One of the main principles of inquiry, namely students can construct their own understanding by conducting active activities in learning [11]. Understanding scientific inquiry is not just taken from the context of certain investigations [12]. However, scientific inquiry is more precisely linked to the stages of the actions of scientists who direct them to scientific knowledge. Although scientific inquiry seems to be associated with some actions of professional scientists, everyone can train their scientific inquiry abilities from everything that is interesting in their daily lives.

Inquiry learning is a two-way communication process between teacher and student in learning where the learning environment conditions are intentionally made, so students are able to think critically and analytically to find answers to a questions.

Inquiry learning models allow students to use all mental process to find scientific concepts or principles and provide many benefits including improving scientific attitudes, intelligence, helping students learn to do research, improve memory, avoid learning and memorizing, develop creativity, increase aspirations, making the teaching process become student centered so that it can help better towards improving higher order thinking skills of students.

\section{RESEARCH METHODS}

This research is carried out at State Elementary School 064985 Medan Helvetia, Postal Code: 20124. The population in this study are all $5^{\text {th }}$ grade students of Public Elementary School 064985 Medan Helvetia Academic Year of 2017-2018. The population in this study is 62 students consisting of two classes $5 \mathrm{~A}$ and $5 \mathrm{~B}$. The sampling technique used is random sampling. This technique is chosen because what is sampled is the number of classes and not the number of students in the population. The design used in this research is pretest-posttest design as can be seen in table 3 .

TABLE 3. RESEARCH DESIGN

\begin{tabular}{ccc}
\hline Pretest & Treatment & Posttest \\
\hline $\mathrm{X} 1$ & T1 (guided inquiry) & Y1 \\
X2 & T2 (free inquiry) & Y2 \\
\hline
\end{tabular}

Notes:

$\mathrm{X} 1$ : Pretest of experimental group before the treatment is given

$\mathrm{X} 2$ : Pretest of control group before the treatment is given

$\mathrm{T} 1$ : Treatment with guided inquiry model

$\mathrm{T} 2$ : Treatment with free inquiry model

Y1 : Posttest of experimental group after the treatment is given

$\mathrm{Y} 2$ : Posttest of control group after the treatment is given
Data collection instrument in this study is learning outcome test. Learning outcome test in this study aims to determine the higher order thinking skills of students in learning ecosystem. The test is in form of essay test. Test indicators are prepared based on Bloom Taxonomy from C4C6. The tests are developed by the researcher herself.

The data analysis technique used in this study is covariate analysis techniques (Anacova). Students learning outcomes in the experimental and control group are compared to see the effectiveness of inquiry learning model and the covariance in this study is the higher order thinking skills of students.

\section{RESULT AND DISCUSSION}

The results in this study are data which is obtained from the pre-test and post-test scores of the students. The instruments in this study have been tested by the experts in order to ensure that the instruments are valid and reliable. The pre-test results are shown in the following table.

TABLE 4. PRE-TEST RESULT OF EXPERIMENTAL AND CONTROL GROUP

\begin{tabular}{ccc|ccc}
\hline \multicolumn{3}{c|}{ Experimental group } & \multicolumn{3}{c}{ Control Group } \\
\hline Score & F & Percentage & Score & F & Percentage \\
\hline $10-19$ & 1 & $3,2 \%$ & $10-19$ & 2 & $6,5 \%$ \\
\hline $20-29$ & 6 & $19,4 \%$ & $20-29$ & 9 & $29,0 \%$ \\
\hline $30-39$ & 5 & $16,1 \%$ & $30-39$ & 8 & $25,8 \%$ \\
\hline $40-49$ & 11 & $35,5 \%$ & $40-49$ & 6 & $19,4 \%$ \\
\hline $50-59$ & 7 & $22,6 \%$ & $50-59$ & 4 & $19,9 \%$ \\
\hline $60-69$ & 1 & $3,2 \%$ & $60-69$ & 2 & $6,5 \%$ \\
\hline Total & 31 & $100 \%$ & Total & 31 & $100 \%$ \\
\hline Mean & 38,87 & & Mean & 35,16 \\
\hline
\end{tabular}

Based on the table 4 above, it can be seen that the higher order thinking skills of students in the beginning of the research are low and both groups (experimental and control) relatively showing the same score. As can be seen that the average score of experimental group is 38,87 , while the average score of students in control group is 35,16 .

After giving pre-test to the two groups, the treatment is applied to those groups. The experimental group is treated by using guided inquiry model and the control group is treated by using free inquiry model. Then, the two groups are given posttest to find out the higher order thinking skills of students after treatment have been given. The post-test result for experimental and control group can be seen from table 5 . 
Table 5. Post-test Result of Experimental and Control Group

\begin{tabular}{lccccccc}
\hline & $\mathrm{N}$ & $\begin{array}{l}\text { Min. } \\
\text { Score }\end{array}$ & $\begin{array}{l}\text { Max. } \\
\text { Score }\end{array}$ & Sum & Mean & $\begin{array}{l}\text { Deviation } \\
\text { Std. }\end{array}$ & Variance \\
\hline $\begin{array}{l}\text { Post test } \\
\text { Experiment }\end{array}$ & 31 & 55.0 & 100.0 & 2500.0 & 80.64 & 10.22 & 194.57 \\
\hline $\begin{array}{l}\text { Post test } \\
\text { Control }\end{array}$ & 31 & 35.0 & 90.0 & 2035.0 & 65.64 & 14.92 & 222.90 \\
\hline $\begin{array}{l}\text { Valid N } \\
\text { (Listwise) }\end{array}$ & 31 & & & & & & \\
\hline
\end{tabular}

From table 5 above, it can be seen that the experimental group which is treated by using guided inquiry learning model obtain average score of 80,64 with deviation standard of 10,22 . While, the control group which is treated by using free inquiry get average score of 65,64 with deviation standard of 14,92 . It shows that the average score of experimental group is higher than the average score of control group.

Based on the data above, it can be stated that Inquiry learning model gives significant effect on higher order thinking skills of students. It also can be stated that Guided Inquiry model has more significant effect on higher order thinking skills of student than the Free Inquiry learning model.

\section{CONCLUSION}

From the result of this study, it can be concluded that guided inquiry learning model gives significant effect on higher order thinking skills of students. Guided Inquiry model gives more significant effect on higher order thinking skills of students than Free Inquiry model.

It is suggested that the teacher, who desires to improve the higher order thinking skills of students, applies Guided Inquiry model. Because Guided Inquiry model gives significant effect on higher order thinking skills of students.

\section{ACKNOWLEDGMENT}

The author gratefully thank to all partners and colleagues who have important roles in conducting this study. The author expects that this study would be useful to all teachers who are going to conduct the same topic of research.

\section{REFERENCES}

[1] A.Lewis and D.Smith, Defining High Order Thinking, Theory into Practice. The Ohio State University: Collage of Education, 2013.

[2] Hasruddin, Memaksimalkan Kemampuan Berpikir Kritis Melalui Pendekatan Kontekstual. Jurnal Tabularsa PPS UNIMDE, 6(1) pp.8-17, 2009

[3] A.Prastya, Strategi Pemilihan Media Pembelajaran Bagi Seorang Guru. Jurnal Temu Ilmiah Nasional Guru (TING), 8(1). pp:294-302, 2016.

[4] A.Kurdi, Penerapan Student Centered Learning dari Teacher Centered Learning. Mata Ajar Ilmu Kesehatan pada Program Studi Penjaskes. Jurnal Forum Kependidikan, 28(2). pp.109-114,2009.

[5] Slameto, Belajar dan Faktor-faktor yang Mempengaruhinya. Jakarta:Rineka Cipta, 2013..

[6] S.Amri dan I.K.Ahmadi, Proses Pembelajaran Kreatif dan Inovatif dalam Kelas. Jakarta: PT.Prestasi Pustakarya, 2010.

[7] E.Mulyasa, Menjadi Guru Profesional Menciptakan Pembelajaran Kreatif dan Menyenangkan. Bandung: PT. Remaja Rosdakarya,2009.

[8] Rusman, Model-model Pembelajaran Mengembangkan Profesionalisme Guru. Bandung: Raja Grafindo Persada, 2010.

[9] R.D.Pertiwi, Penerapan Constructive Controversy dan Modified Free Inquiry terhadap Keterampilan Berpikir Tingkat Tinggi Mahasiswa Pendidikan Biologi. Jurnal Pendidikan Biologi UIN Syarif Hidayatullah Jakarta. 7(2) pp.34-45,2014.

[10] L.W.Anderson and Krathwohl, Kerangka Landasan untuk: Pembelajaran, Pengajaran dan Asesmen. Yogyakarta: Pustaka Pelajar, 2010.

[11] Zulfiani, Strategi Pembelajaran Sains. Jakarta: Lembaga Penlitian UIN Jakarta, 2009

[12] S.K.Umah, Pengembangan Petunjuk Praktikum IPA Terpadu Berbasis Inkuiri Terbimbing pada Tema Makanan dan Kesehatan. UNNES Science Education Journal, 3(2) pp.34-36,2014. 